\title{
F. Grenet. Iranian Gods in Hindu Garb: the Zoroastrian Pantheon of the Bactrians and Sogdians, Second-Eighth Centuries
}

\section{Rika Gyselen}

\section{(2) OpenEdition \\ 1 Journals}

\section{Édition électronique}

URL : http://journals.openedition.org/abstractairanica/40802

DOI : 10.4000/abstractairanica.40802

ISSN : 1961-960X

Éditeur :

CNRS (UMR 7528 Mondes iraniens et indiens), Éditions de l'IFRI

\section{Édition imprimée}

Date de publication : 1 décembre 2013

ISSN : 0240-8910

Référence électronique

Rika Gyselen, «F. Grenet. Iranian Gods in Hindu Garb: the Zoroastrian Pantheon of the Bactrians and Sogdians, Second-Eighth Centuries », Abstracta Iranica [En ligne], Volume 32-33 | 2013, document 308, mis en ligne le 01 juillet 2016, consulté le 26 septembre 2020. URL : http://journals.openedition.org/ abstractairanica/40802 ; DOI : https://doi.org/10.4000/abstractairanica.40802

Ce document a été généré automatiquement le 26 septembre 2020

Tous droits réservés 


\title{
F. Grenet. Iranian Gods in Hindu Garb: the Zoroastrian Pantheon of the Bactrians and Sogdians, Second- Eighth Centuries
}

\author{
Rika Gyselen
}

\section{RÉFÉRENCE}

F. Grenet. « Iranian Gods in Hindu Garb: the Zoroastrian Pantheon of the Bactrians and Sogdians, Second-Eighth Centuries ». Bulletin of the Asia Institute, 20, 2006 [paru en 2010], p. 87-99.

1 L'A. fournit de nombreux exemples de personnages représentant des divinités zoroastriennes en Bactriane ( $\mathrm{I}^{\mathrm{er}}-\mathrm{IV} \mathrm{V}^{\mathrm{e}} \mathrm{s}$.) et en Sogdiane, alors que les textes zoroastriens n'évoquent que très peu le caractère anthromorphique des divinités. Dans ces régions est-iraniennes, les artistes ont fait appel à une iconographie, non-iranienne, pour caractériser les divinités zoroastriennes. Ce sont les divinités du panthéon grec et hindu, dont le rôle est souvent comparable à celui des divinités zoroastriennes, qui procurent les éléments iconographiques pour donner allure humaine à ces dernières. 


\section{AUTEURS}

\section{RIKA GYSELEN}

CNRS, Mondes iranien et indien, Paris 